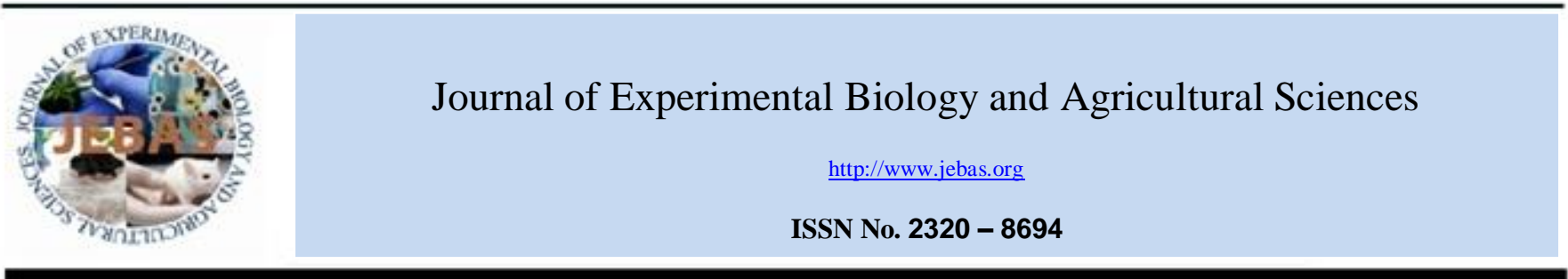

\title{
INNOVATIVE POLYHOUSE FOR PRODUCTION OF BUTTON MUSHROOMS (Agaricus bisporus) IN HOT REGIONS
}

\author{
Sakharam Kale ${ }^{1}$, Prerna Nath ${ }^{1}$, VS Meena ${ }^{1}$, Devender Kumar ${ }^{1}$, RK Singh ${ }^{2}$ \\ ${ }^{1}$ ICAR-Central Institute of Postharvest Engineering and Technology, Abohar, Punjab, India \\ ${ }^{2}$ ICAR-Central Institute of Postharvest Engineering and Technology, Ludhiana, Punjab, India
}

Received - September 13, 2018; Revision - October 15, 2018; Accepted - November 05, 2018

Available Online - December 15, 2018

DOI: http://dx.doi.org/10.18006/2018.6(6).903.911

\author{
KEYWORDS \\ Polyhouse \\ Heat load \\ Evaporative cooling \\ Button mushroom \\ Temperature
}

\begin{abstract}
An innovative polyhouse was developed for production of button mushrooms in hot region of Punjab. Length, width and ridge height of polyhouse was 15,4 and $4.27 \mathrm{~m}$, respectively. Floor was kept at $1 \mathrm{~m}$ below ground level. Roof was thermally insulated whereas walls were ventilated. Heat load analysis of polyhouse was carried out in the study. Polyhouse was equipped with fan-pad system and foggers to attain cooling through evaporative cooling mechanism. Water required to reduce the inside temperature by $10^{\circ} \mathrm{C}$ was determined as 1.3 liters. Performance of polyhouse was evaluated in terms of attaining the desirable temperature and humidity conditions. Results indicated that on operating the cooling systems, inside temperature and $\mathrm{RH}$ during October were $22-27^{\circ} \mathrm{C}$ and $\geq 75 \%$, respectively. These conditions were suitable for spawn run. In November polyhouse provided $20-22^{\circ} \mathrm{C}$ temperature and $\geq 75 \% \mathrm{RH}$. These conditions were suitable for case run and fruiting. Favorable temperatures and RH were achieved during February and March also. Thus, study demonstrated that, in hot region, button mushroom farming may be started in October month and can be carried out till March using polyhouse developed in study.
\end{abstract}

* Corresponding author

E-mail: sakha_yogesh@yahoo.co.in (Sakharam Kale)

Peer review under responsibility of Journal of Experimental Biology and Agricultural Sciences.

Production and Hosting by Horizon Publisher India [HPI] (http://www.horizonpublisherindia.in/).

All rights reserved.
All the article published by Journal of Experimental Biology and Agricultural Sciences is licensed under a Creative Commons Attribution-NonCommercial 4.0 International License Based on a work at www.jebas.org.

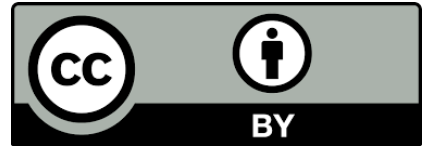




\section{Introduction}

Button mushrooms (Agaricus bisporus) are the fruiting bodies of fungus containing proteins, vitamins, fibers and minerals (Kaur \& Rampal, 2017). Protein content of button mushrooms varies from 20 to $35 \%$ (d.b.) which is higher than many fruits and vegetables (Thakur, 2014). Commercially produced button mushrooms contain $90 \%$ moisture content (w.b.), 3\% proteins (w.b.), 5\% carbohydrates (w.b.), $1 \%$ fats (w.b.) and $1 \%$ minerals and vitamins. Consequently, they are the crucial food items concerning human health, nutrition and disease prevention (Chang, 1996). Moreover, mushrooms are acknowledged by FAO as food contributing to protein nutrient in diet of developing countries where most of the population is heavily dependent on cereal/starchy diets (Karthick \& Hamsalakshmi, 2017).

On considering the health importance of button mushrooms, their farming was started in India during 1960s in temperate region due to availability of favorable climate in region. Huge amount of agricultural wastes in the form of wheat and paddy straw, availability of suitable strains and farming techniques contributed to growth and diversification of mushrooms in the country (Maheshwari, 2013). Presently, total mushroom production of the country is 4,59,000 MT (Anonymous, 2017). The leading mushroom species produced in the country include button, oyster and paddy straw mushrooms. However, button mushrooms alone contribute almost $90 \%$ of total mushroom production of the country (Mehta et al., 2011).

Literature reveals that yield and quality of button mushrooms predominantly depends on environment inside mushroom house. Indeed, button mushrooms are very sensitive to environmental factors (Van Peer et al., 2009). Major environmental factors affecting button mushroom yield and quality are temperature, relative humidity $(\mathrm{RH})$, oxygen and carbon dioxide $\left(\mathrm{CO}_{2}\right)$ concentration (Schmidt, 1983; Stamets, 1993; AMGA, 2004; Sarker et al., 2008). Attainment of desirable environment in mushroom house is very crucial. For button mushroom farming, recommended temperature is 22 $26^{\circ} \mathrm{C}$ during spawn run, $18-22^{\circ} \mathrm{C}$ during case run and $14-18^{\circ} \mathrm{C}$ during fruiting. Recommended RH during spawn and case run is $80-90 \%$ and during fruiting it should be $85-95 \%$. Concentration of $\mathrm{CO}_{2}$ plays a vital role during spawn run. It is recommended that $\mathrm{CO}_{2}$ concentration should be maintained at $>1500 \mathrm{ppm}$ during spawn run. However, it should to be maintained between $800-1000 \mathrm{ppm}$ during fruiting period of mushroom (http://agridaksh.iasri.res.in).

Mushroom house provides the major interface between crop environment and ambient environment. It requires suitable arrangements to create desirable microclimate. Number of different small scale and commercial mushroom houses has been developed by various researchers (Kwon et al., 2004; Mabveni, 2004; Reyes et al., 2004; Dhar \& Arumuganathan, 2005; Arumuganathan et al., 2010; Schiau, 2013). Variety of square, rectangular, curved, polyethylene covered tunnels with a range of cross-sections and shapes have been studied (Han et al., 2009; Schiau, 2013). However, in India, most of the mushroom farmers still grow button mushrooms in very temporary structures made of locally available materials. These structures lack heating, ventilation and airconditioning (HVAC) facilities and unable to isolate mushroom environment from atmospheric environment. Some farmers constructed permanent structures with HVAC arrangements. These structures provide all essential requirements to crop but are costly and involve considerable cost of cooling and ventilation. Under such circumstances polyhouse technology, having intermediate cost, adequate life span (10-15 years) and maximum isolation of crop environment from surrounding environment, may be adopted in mushroom farming (Staunton, 1988).

In India, button mushroom farming is largely restricted to temperate region, consisting of Indian states of Himachal Pradesh and Jammu-Kashmir. However, due to large consumer demand, its farming may also be adopted in adjoining states like Punjab and Rajasthan by technological interventions in mushroom houses (Kaur \& Rampal, 2017; Kumar et al., 2018). The climate of these states is categorized as hot and semi-arid. Temperature $\left(14-18^{\circ} \mathrm{C}\right)$ desired for button mushroom farming is available in hot and semi-arid region from December to February (for 2-3 months) during which one crop is easily grown. However, after March, ambient temperature increases sharply making button mushroom farming difficult in region. Therefore, an innovative mushroom house that can provide desired temperature for more duration (November to March) may prove good in the region for production of 2-3 crops of button mushrooms.

Literature revealed that lot of research has been carried on mushroom production technology, development of mushroom varieties, post-harvest management of mushrooms etc. However, almost no work has been devoted on developing crop specific polyhouse suitable for farming of button mushrooms in hot region. Hence, an attempt was made in present study to develop intermediate cost, durable, completely protected polyhouse for mushroom farming. The main objective of study was to develop polyhouse for button mushroom farming in hot region of northwestern India and to evaluate its performance in terms of attaining desirable temperature and RH inside polyhouse during off-season period viz. October, November and March. 


\section{Materials and Methods}

\subsection{Experimental site}

Experimental site is located in hot and semi-arid region of northwestern India. This region comprises of parts of Punjab, Haryana and Rajasthan. Description of experimental site is presented in Table 1. Mean monthly temperature and RH data was recorded at experimental site prior to study. This data indicated that maximum temperature in May-July reached up to $49^{\circ} \mathrm{C}$ whereas minimum temperature in December-January dropped to $0^{\circ} \mathrm{C}$. Atmospheric RH dropped to $10 \%$ during May-June. This data revealed that polyhouse proposed for button mushroom farming should be capable of lowering the temperature by reducing heat gain during October, November and March months. Similarly, it should be able to increase inside temperature to optimum level by preventing heat loss during chilling winter.

\subsection{Development of mushroom polyhouse}

Crop specific polyhouse was developed according to functional requirement of button mushroom crop. Its roof was insulated and walls were ventilated (Figure1). The details of the structural components of polyhouseare presented below.

\section{* Orientation - east-west direction}

* Dimensions - length - $15 \mathrm{~m}$, width - $4 \mathrm{~m}$, ridge height $-4.27 \mathrm{~m}$

* Roof - ridge height from floor: $4.27 \mathrm{~m}$; eve height from floor - $2.13 \mathrm{~m}$. Multi-layer roof composed of iron net (half inch
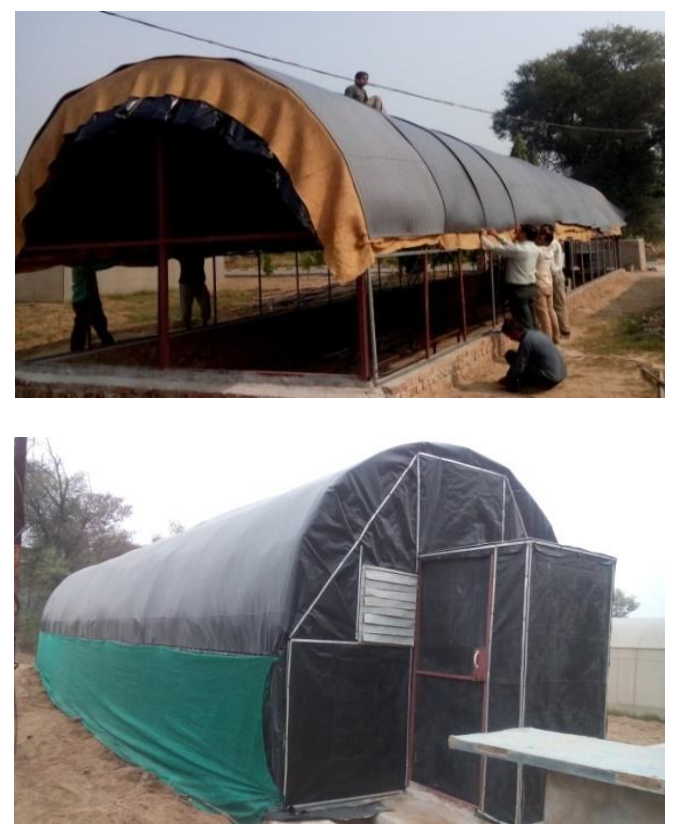

Figure 1Polyhouse developed for button mushroom farming in hot region

Journal of Experimental Biology and Agricultural Sciences http://www.jebas.org mesh), polythene sheet $(0.025 \mathrm{~mm}$ thick), jute sheet $(3 \mathrm{~mm}$ thick), EPF thermocol sheet ( $8 \mathrm{~mm}$ thick) and UV stabilized polythene sheet $(0.4 \mathrm{~mm}$ thick). Thermal conductivities of all these materials are listed in Table 2.

* Floor - floor material: single layer vertical brick. Floor of polyhouse was kept at $1 \mathrm{~m}$ deep below ground level. Aim of

Table 1 Description of the experimental site

\begin{tabular}{|ll|}
\multicolumn{1}{|c|}{ Attribute } & \multicolumn{1}{c|}{ Description } \\
\hline Location & ICAR-CIPHET, Abohar, Punjab \\
\hline Latitude & $30.17^{\circ} \mathrm{N}$ \\
\hline Longitude & $74.18^{\circ} \mathrm{E}$ \\
\hline Altitude & $390 \mathrm{~m}$ above the mean sea level \\
\hline Average annual rainfall & $328 \mathrm{~mm}(200-500 \mathrm{~mm})$ \\
\hline Monthly Averaged Insolation & $5.07 \mathrm{kWh} / \mathrm{m}^{2} /$ day \\
\hline Ground water table & up to $2 \mathrm{~m}$ \\
\hline
\end{tabular}

Table 2 Thermal conductivities of different materials used in roof

\begin{tabular}{|lcc|}
\hline \multicolumn{1}{|c}{ Roof material } & $\begin{array}{c}\text { Thickness } \\
(\mathrm{mm})\end{array}$ & $\begin{array}{c}\text { Thermal } \\
\text { conductivity }\end{array}$ \\
\hline EPF thermocol & $8 \mathrm{~mm}$ & $0.0245 \mathrm{~W} / \mathrm{m} . \mathrm{K}$ \\
\hline Jute sheet & $3 \mathrm{~mm}$ & $0.25 \mathrm{~W} / \mathrm{m} . \mathrm{K}$ \\
\hline $\begin{array}{l}\text { UV stabilized black } \\
\text { polythene sheet }(300 \mathrm{gsm})\end{array}$ & $0.4 \mathrm{~mm}$ & $0.45 \mathrm{~W} / \mathrm{m} . \mathrm{K}$ \\
\hline LDPE Polythene sheet & $0.025 \mathrm{~mm}$ & $0.33 \mathrm{~W} / \mathrm{m} . \mathrm{K}$ \\
\hline
\end{tabular}
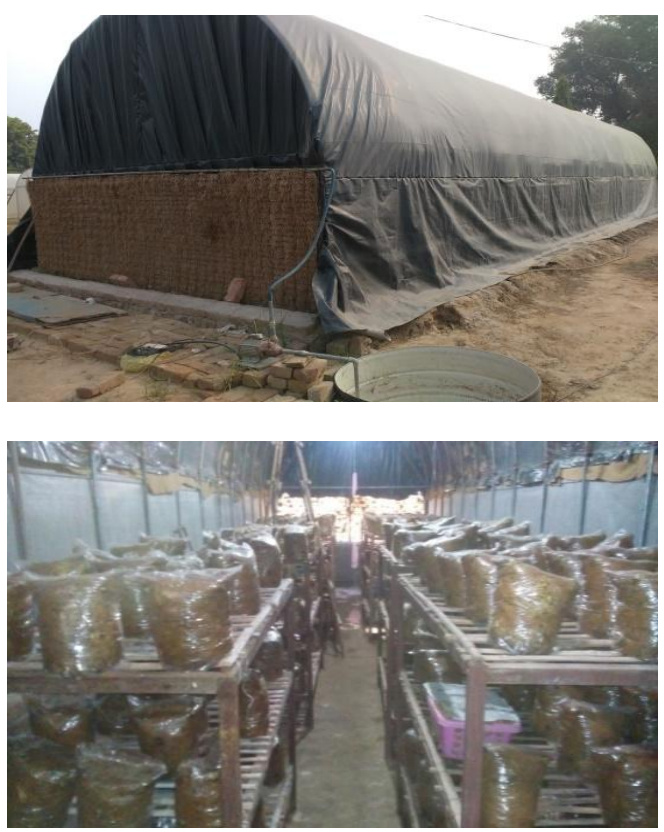
lowering the floor was to provide extra height to polyhouse with minimized risk of overturning due to strong winds. It was also aimed at achieving more cooling effect through evaporative cooling system.

* Foundation walls - height $-1.22 \mathrm{~m}$, width $-0.2 \mathrm{~m}$

* Walls - Front wall- center height - 4.27 m. Front wall was provided with two 18 inch exhaust fans. Rear wall - center height was- $4.27 \mathrm{~m}$. Side walls - composed of foundation wall (lower half) made of brick - $1.22 \mathrm{~m}$ height; and porous wall (upper half) made of insect proof net and UV-stabilized polythene.

* Door - double door frame was used to prevent the entry of insects and pests in to the structure.

\subsection{Temperature profile inside polyhouse}

After its construction, temperatures at nine different locations inside polyhouse were recorded under no crop load condition. Temperature sensors (PT 100 probes) of datalogger (sixteen channel, make: Intronix India, New Delhi) were installed in a grid of three tiers having three thermometers in a tier at nine locations (Figure 2). Temperatures were recorded at an interval of $30 \mathrm{~min}$. The data was recorded continuously for six months. No cooling was provided to polyhouse during this period.

\subsection{Heat load analysis of polyhouse}

Heat load analysis was carried out using different equations described by Holman (1989). Heat load was the total heat accounted for increasing inside temperature of polyhouse. Total heat gained $\left(\mathrm{Q}_{\mathrm{T}}\right)$ inside polyhouse was due to,

- heat inflow from surroundings $\left(\mathrm{Q}_{\mathrm{s}}\right)$

- heat generated by compost $\left(\mathrm{Q}_{\mathrm{C}}\right)$

- heat generated by workers $\left(\mathrm{Q}_{\mathrm{W}}\right)$

- heat generated by data logger, battery etc. (QD)

$\mathrm{Q}_{\mathrm{T}}=\mathrm{Q}_{\mathrm{S}}+\mathrm{Q}_{\mathrm{C}}+\mathrm{Q}_{\mathrm{W}}+\mathrm{Q}_{\mathrm{D}}$

However, amount $\mathrm{Q}_{\mathrm{C}}, \mathrm{Q}_{\mathrm{W}}$ and $\mathrm{Q}_{\mathrm{D}}$ were very small in comparison to $\mathrm{Q}_{\mathrm{S}}\left(\mathrm{Q}_{\mathrm{C}} \gg \mathrm{Q}_{\mathrm{C}}, \mathrm{Q}_{\mathrm{W}}, \mathrm{Q}_{\mathrm{D}}\right)$. Hence only $\mathrm{Q}_{\mathrm{s}}$ was considered for heat load analysis during study.

Qs had two components: heat gained through roof $\left(\mathrm{Q}_{\mathrm{R}}\right)$ and heat gained through walls $\left(\mathrm{Q}_{\mathrm{w}}\right)$.Surface areas of roof and wallsexposed to surrounding were determined using Figure 3. Roof surface area $\left(A_{R}\right)$ was calculated as $89.38 \mathrm{~m}^{2}$ whereas wall surface area $\left(A_{W}\right)$ was $66.23 \mathrm{~m}^{2}$.

Heat gained through roof $\left(\mathrm{Q}_{\mathrm{R}}\right)$ was determined using Eq.1.

$$
\mathrm{Q}_{\mathrm{R}}=\mathrm{U}_{\mathrm{R}} \mathrm{A}_{\mathrm{R}} \Delta \mathrm{T}
$$

$\mathrm{U}_{\mathrm{R}}$ was determined using Eq.2

$$
\frac{1}{\mathrm{U}_{\mathrm{R}}}=\frac{1}{\mathrm{~h}_{\mathrm{i}}}+\frac{\mathrm{x}_{\mathrm{P}}}{\mathrm{K}_{\mathrm{P}}}+\frac{\mathrm{x}_{\mathrm{J}}}{\mathrm{K}_{\mathrm{J}}}+\frac{\mathrm{x}_{\mathrm{F}}}{\mathrm{K}_{\mathrm{F}}}+\frac{\mathrm{x}_{\mathrm{U}}}{\mathrm{K}_{\mathrm{U}}}+\frac{1}{\mathrm{~h}_{\mathrm{o}}}
$$

Where, $\mathrm{Q}_{\mathrm{R}}=$ heat gained through $\operatorname{roof}(\mathrm{W})$

$\mathrm{U}_{\mathrm{R}}=$ overall heat transfer coefficient of $\operatorname{roof}\left(\mathrm{W} / \mathrm{m}^{2} \mathrm{~K}\right)=2.29$

$\mathrm{A}_{\mathrm{R}}=$ roof area $\left(\mathrm{m}^{2}\right)$

$\Delta \mathrm{T}=$ temperature difference of inside and outside of roof $\left({ }^{\circ} \mathrm{C}\right)$

$\mathrm{h}=$ convective heat transfer coefficient of air at low speed $\left(\mathrm{W} / \mathrm{m}^{2} \cdot \mathrm{K}\right)$

$\mathrm{X}=$ layer thickness $\left(\mathrm{X}_{\mathrm{P}}=\right.$ polythene, $\mathrm{X}_{\mathrm{J}}=$ jute, $\mathrm{X}_{\mathrm{F}}=$ foam, $\mathrm{X}_{\mathrm{U}}=\mathrm{UV}$ stabilized polythene)

$\mathrm{K}=$ thermal conductivity of layers $\left(\mathrm{K}_{\mathrm{P}}=\right.$ polythene, $\mathrm{K}_{\mathrm{J}}=$ jute, $\mathrm{K}_{\mathrm{PF}}=$ foam, $\mathrm{K}_{\mathrm{U}}=\mathrm{UV}$-stabilized polythene)

Heat gained through wall $\left(\mathrm{Q}_{\mathrm{w}}\right)$ was determined using Eq.3.

$$
\mathrm{Q}_{\mathrm{W}}=\mathrm{U}_{\mathrm{W}} \mathrm{A}_{\mathrm{W}} \Delta \mathrm{T}
$$

$\mathrm{U}_{\mathrm{W}}$ was determined using Eq.4

$$
\frac{1}{\mathrm{U}_{\mathrm{W}}}=\frac{1}{\mathrm{~h}_{\mathrm{i}}}+\frac{\mathrm{x}_{\mathrm{U}}}{\mathrm{K}}+\frac{1}{\mathrm{~h}_{\mathrm{o}}}
$$

Where, $\mathrm{U}_{\mathrm{W}}=$ overall heat transfer coefficient of wall $\left(\mathrm{W} / \mathrm{m}^{2} . \mathrm{K}\right)=$ 9.12

$\mathrm{A}_{\mathrm{W}}=$ surface area of wall $\left(\mathrm{m}^{2}\right)$

$\Delta \mathrm{T}=$ temperature difference of inside and outside of wall $\left({ }^{\circ} \mathrm{C}\right)$

\subsection{Cooling of mushroom polyhouse}

Two evaporative cooling systems, fogger and fan-fad, were installed to attain desired temperature and $\mathrm{RH}$ conditions inside polyhouse.

\subsection{Foggers}

During spawn and case run polyhouse should be closed with no air exchange in order to achieve desirable $\mathrm{CO}_{2}$ concentration (Maheshwari, 2013). Therefore, during this period cooling is possible with foggers only. Fan-pad system would reduce $\mathrm{CO}_{2}$ concentration and hence may not be advisable. Six overhead foggers having total discharge of 24 liters/h were installed along the ridge line of the polyhouse.

\subsection{Fan-pad system}

It was useful during fruiting period as air exchange is desirable during fruiting stage. The cooling pad was made of khus 
(Chrysopogon zizanioides) with dimensions as length $3.96 \mathrm{~m}$, height $1.37 \mathrm{~m}$ and thickness $3-4 \mathrm{~cm}$. The reason behind selecting khus as padding materials over other organic materials was that air flow through khus pad was higher as compared to wood wool and coconut coir pad (Shekhar et al., 2016). Khus pads were tied to galvanized iron wire mesh to prepare a cooling pad. Two electric exhaust fans with 4 straight blades and 18 inches sweep were used for achieving air exchange in polyhouse.

\subsection{Performance evaluation of evaporative cooling systems}

Both evaporative cooling systems were operated in polyhouse for predetermined interval of time and their effect on inside temperature, $\mathrm{RH}$ and $\mathrm{CO}_{2}$ concentration was determined. Temperature was measured using infrared temperature meter (MecoIrt 380 infrared thermometer, Spark India System, Gwalior, India), RH was measured using wet and dry bulb hygrometer (Zeal P2501,Zeal, UK) whereas $\mathrm{CO}_{2}$ concentration was measured with the help of $\mathrm{CO}_{2}$ concentration meter (KusamMeco KM 6460, Mumbai, India). $\mathrm{RH}$ and $\mathrm{CO}_{2}$ concentration were measured at three locations, close to east wall, at center and close to west wall, and average values were determined. Temperature was measured at various locations along length and height of polyhouse as given below.

Locations of temperature measurement along length

- $\quad$ Lengths $(\mathrm{m}): 1.5, \quad 3.0,4.5,6.0,7.5,9.0,10.5$, $12.0,13.515 .0$ (10 locations)

- $\quad$ Operation time ( $\min ): 5,10,20,30,40,50,60$

Locations of temperature measurement along height

- Height (m): 0.61, 1.07, 1.52, 1.98, 2.44, 2.90, 3.35, 3.81 (8 locations)

- Operation time (min): 5, 10, 20, 30, 40, 50, 60

2.9 Water requirement for cooling of polyhouse using evaporative cooling systems

Amount of water required to cool polyhouse using evaporative cooling systems was calculated using following equation (Eq. 5).

$$
\mathrm{V} \times \rho \times \mathrm{C} \times \Delta \mathrm{T}=\frac{d_{m}}{d_{t}} \times \lambda
$$

Where, $\mathrm{V}=$ volume of polyhouse $\left(\mathrm{m}^{3}\right)$

$$
\begin{aligned}
& \rho=\text { density of air }\left(\mathrm{kg} / \mathrm{m}^{3}\right) \\
& \mathrm{C}=\text { specific heat of air }(\mathrm{kJ} / \mathrm{kg}) \\
& \Delta \mathrm{T}=\text { temperature difference }\left({ }^{\circ} \mathrm{C}\right) \\
& \mathrm{m}=\text { mass of water required }(\mathrm{kg}) \\
& \lambda=\text { latent heat of water }(2257 \mathrm{~kJ} / \mathrm{kg})
\end{aligned}
$$

Tier 1 (T3, T6, T9): $1 \mathrm{~m}$ height

Tier 2 (T2, T5, T8): $2 \mathrm{~m}$ height

Tier 3 (T1, T4, T7): $3 \mathrm{~m}$ height

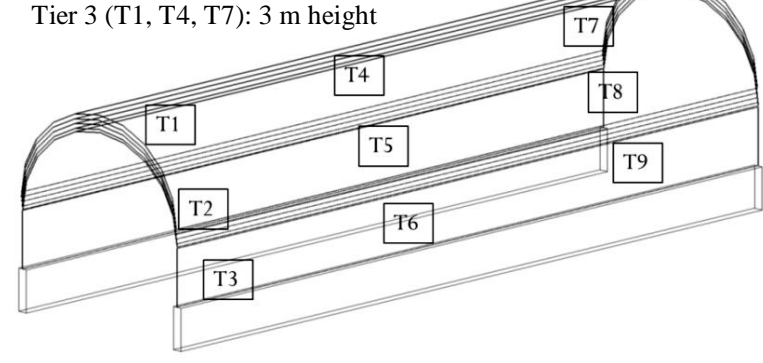

Figure 2 Locations of temperature sensors inside polyhouse

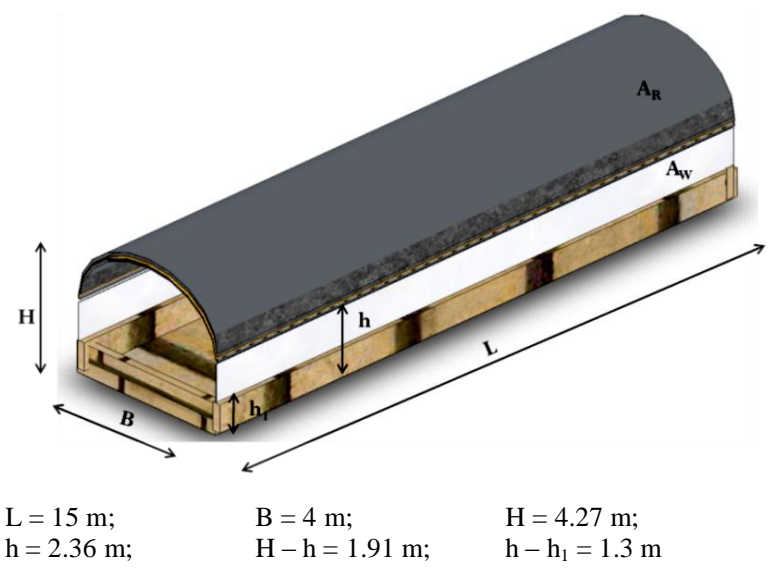

Figure 3 Surface area exposed to the surrounding

\subsection{Performance evaluation of polyhouse}

Performance of polyhouse was evaluated in terms of attaining the desired temperature and RH conditions during off-season period. October, November and March months were considered as offseason period. Button mushroom crop was grown in polyhouse as per standard practice (Maheshwari, 2013). Cultivation season was started in October 2016 to mid-March 2017, about 5 to 5.5 months. Two consecutive crops of button mushroom were cultivated during this period. Spawn was obtained from ICARDirectorate of Mushroom Research, Solan, India whereas compost was prepared at experimental site.

\section{Results and Discussion}

\subsection{Thermal analysis of polyhouse}

Temperature at different nine locations inside polyhouse (Figure 2) was recorded under no crop load condition for six consecutive months. It was found that different locations in polyhouse attained different temperatures (Figure 4$)$. The highest temperature $\left(49^{\circ} \mathrm{C}\right)$ was recorded at locations in the uppermost tier (T1) and (T4) whereas the lowest temperature $\left(39^{\circ} \mathrm{C}\right)$ was found at $\mathrm{T} 9$ located in bottom tier. Lower tier showed considerably lower temperatures 


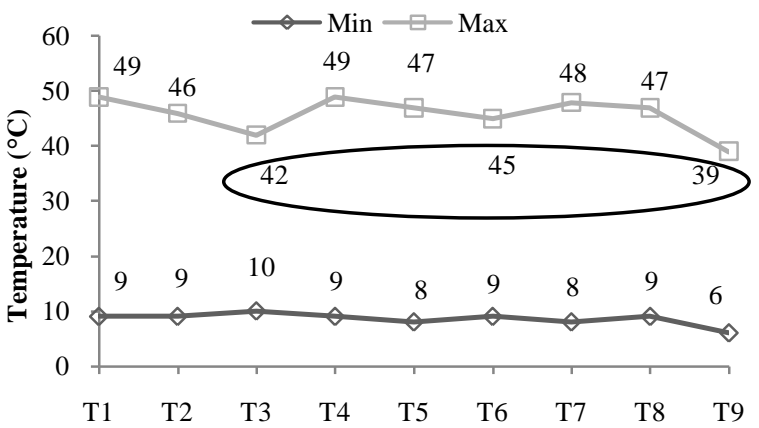

Location of sensor inside polyhouse

Figure 4 Temperature variation inside polyhouse

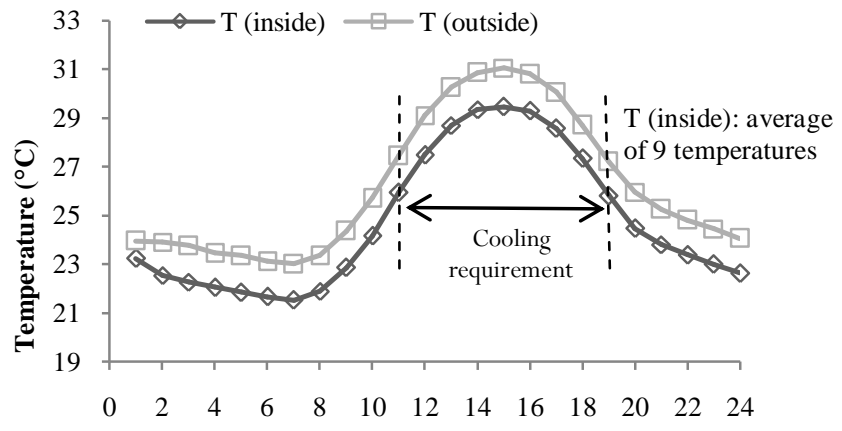

Time in clock of $24 \mathrm{~h}(\mathrm{~h})$

Figure 5 Temperature behavior inside and outside the structure in October month

Table 3 Heat gained by structure during different months

\begin{tabular}{|c|c|c|c|c|c|c|c|c|}
\hline \multirow{2}{*}{ Month } & \multirow{2}{*}{$\begin{array}{c}\text { Average } \\
\text { Outside temp } \\
\left({ }^{\circ} \mathrm{C}\right)\end{array}$} & \multicolumn{3}{|c|}{ Roof } & \multicolumn{3}{|c|}{ Wall } & \multirow{2}{*}{$\begin{array}{l}\text { Total heat gain } \\
\qquad\left(\mathrm{Q}_{\mathrm{T}} \text { in } \mathrm{W}\right)\end{array}$} \\
\hline & & Area $\left(m^{2}\right)$ & $\mathrm{Ur}\left(\mathrm{W} / \mathrm{m}^{2} \mathrm{~K}\right)$ & $\mathrm{Q}_{\mathrm{R}}(\mathrm{W})$ & Area $\left(\mathrm{m}^{2}\right)$ & $\mathrm{U}_{\mathrm{W}}\left(\mathrm{W} / \mathrm{m}^{2} \mathrm{~K}\right)$ & $\mathrm{Q}_{\mathrm{w}}(\mathrm{W})$ & \\
\hline October & 31 & 89.38 & 2.29 & 371.79 & 66.23 & 9.12 & 2479.3 & 2545.51 \\
\hline November & 26 & 89.38 & 2.29 & 638.04 & 66.23 & 9.12 & 1010.3 & 1648.3 \\
\hline December & 16 & 89.38 & 2.29 & 321.2 & 66.23 & 9.12 & 612.3 & 933.5 \\
\hline January & 15 & 89.38 & 2.29 & 293.5 & 66.23 & 9.12 & 692.1 & 985.4 \\
\hline February & 20 & 89.38 & 2.29 & 381.6 & 66.23 & 9.12 & 863.2 & 1244.8 \\
\hline March & 23 & 89.38 & 2.29 & 492.5 & 66.23 & 9.12 & 2132.1 & 2624.8 \\
\hline
\end{tabular}

as compared to other six locations. It might be due to tall height of the polyhouse and placement of floor below ground level.

Outside temperature and temperatures inside polyhouse at nine different locations (Figure 2) were continuously recorded for $24 \mathrm{~h}$ in October month. Average inside temperature was plotted against time and presented in Figure 5. Cooling requirement was understood from this plot. Figure 5 indicates that both inside and outside temperatures were almost constant till 8:00 am in morning. After 8:00 am, they increased till 3:00 pm in the afternoon and again decreased. Results indicated that the polyhouse needed external cooling from 11:00 am in morning to 7:00 pm in evening.

\subsection{Heat load in polyhouse}

Total heat gained by polyhouse during October to March, growing season of button mushrooms in temperate region, was determined and presented in Table 3. It is evident from Table 3 that heat gained by polyhouse was dependent on outside temperature and varied with month of year. Average outside temperature during
October 2016 was observed as $31^{\circ} \mathrm{C}$ and total heat gained by polyhouse during this month was calculated as $2545.51 \mathrm{~W}$. However, during January 2017, average outside temperature was observed as $15^{\circ} \mathrm{Cand}$ total heat gained by polyhouse was $985.4 \mathrm{~W}$. Consequently, cooling requirement varied with the month. Maximum cooling was required during March and October whereas almost no cooling was required during December and January.

\subsection{Water requirement for evaporative cooling systems}

The aim of cooling systems was to lower polyhouse temperature by removing inside heat through evaporative cooling principle. In present study, temperature rise in polyhouse above the desired temperature for mushroom farming was determined as $10^{\circ} \mathrm{C}$. Theoretically, water required to reduce inside temperature using evaporative cooling principle was determined as 0.13 liter per ${ }^{\circ} \mathrm{C}$. Therefore, water required to reduce inside temperature by $10^{\circ} \mathrm{C}$ was 1.3 liter. However, in practical sense, polyhouse was gaining the heat continuously from the sun. Hence, more water required to attain desired temperature. 


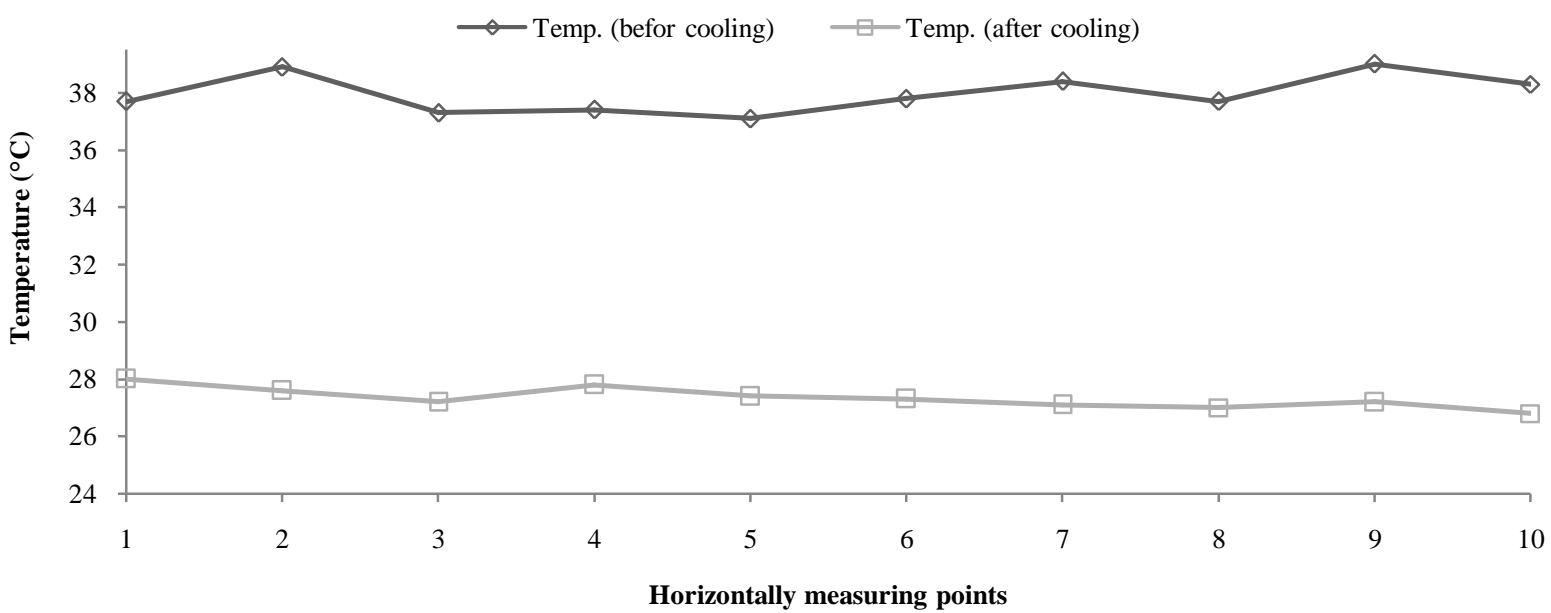

Figure 6 Variation in inside temperature along the length due to fan-pad cooling operation

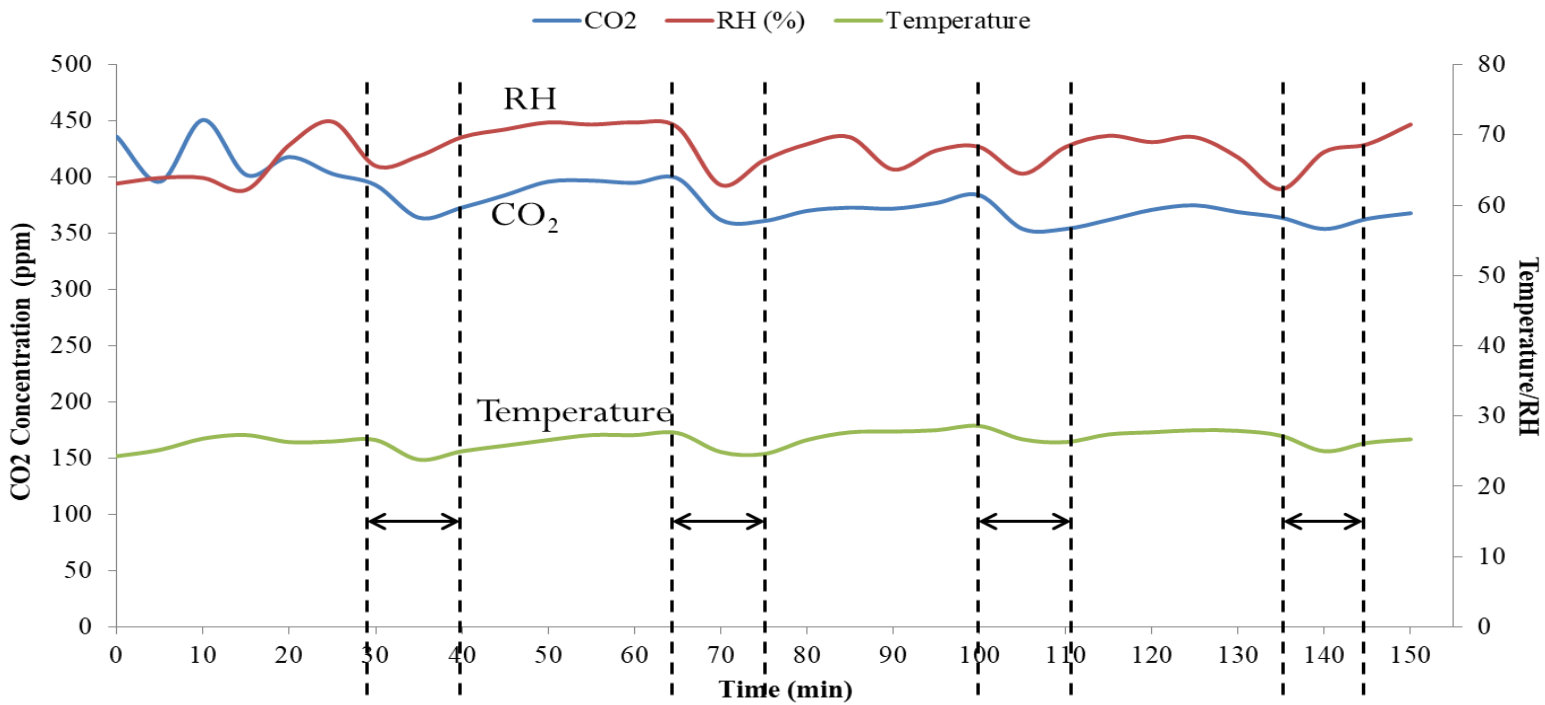

Figure 7 Variation in Temperature, $\mathrm{RH}$ and $\mathrm{CO}_{2}$ concentration due to fan-pad system

\subsection{Performance evaluation of evaporative cooling systems}

Fan-pad system and foggers were operated independently and their effect on temperature and $\mathrm{RH}$ inside polyhouse was determined at different pre-determined locations.

\subsection{Effect of fan-pad system on inside temperature and $R H$}

During October-November, fan-pad system was operated for 10$60 \mathrm{~min}$ and variation in inside temperature along the length was determined (Figure 6). It was observed that after $60 \mathrm{~min}$ of operation, temperatures inside mushroom polyhouse at all 10 locations were almost same. Before cooling, inside temperatures at 10 different locations were $37-39^{\circ} \mathrm{C}$ and on operating fan-pad system for 60 minutes, these temperatures reduced to $27-28^{\circ} \mathrm{C}$ i.e. almost $10^{\circ} \mathrm{C}$ reduction (Figure 6).

Variation in inside temperature (average of 10 locations) and $\mathrm{RH}$ with operating time was also determined in study during October, November and March. Results revealed that initial average inside temperature was $28 \pm 2^{\circ} \mathrm{C}$ and it decreased with time till $30 \mathrm{~min}$ of operation. However, after 30 minutes it became almost constant (about $21 \pm 2^{\circ} \mathrm{C}$ ) with no further decrease in temperature. Similarly, inside RH was found to be about $76 \%$ after $30 \mathrm{~min}$ of operation. These conditions were more or less conducive for spawn run, case run and to some extent fruiting of button mushroom. 
Fan-pad system draws inside air out and brings fresh air in. Consequently, it reduces $\mathrm{CO}_{2}$ concentration inside polyhouse. In Figure 7, horizontal arrows indicate that fan-pad system was $\mathrm{ON}$ for this period. Figure 7 also shows that temperature and $\mathrm{CO}_{2}$ concentration inside structure decreased whereas $\mathrm{RH}$ increased when cooling was ON. Fan-pad system maintained the inside temperature about $24^{\circ} \mathrm{C}, \mathrm{RH}$ about $70 \%$ and $\mathrm{CO}_{2}$ level about 400 ppm. Thus, it could be inferred that although fan-pad system lowered inside temperature, it lowered $\mathrm{CO}_{2}$ level also. Such low concentration of $\mathrm{CO}_{2}$ is undesirable during spawn and case run. Hence, fan-pad system should not be operated during this period.

\subsection{Effect of fogger system on inside temperature and $R H$}

Fogger system was operated for six different operating times ranging from $10-60 \mathrm{~min}$ and variation in inside temperature (average of 10 locations inside structure) and $\mathrm{RH}$ with operating time was determined. Results indicated that initial inside temperature was $29 \pm 2{ }^{\circ} \mathrm{C}$ and it decreased with time till $20 \mathrm{~min}$ of operation. However, after $20 \mathrm{~min}$ of operation, it became almost constant (about $22 \pm 3^{\circ} \mathrm{C}$ ) with no further decrease in temperature. Similarly, inside RH was found to be about $78 \%$ after 20 min of operation. These conditions were found conducive for spawn run, case run and to some extent fruiting stage of button mushroom.

\subsection{Crop production}

Two consecutive crops of button mushroom were cultivated in developed polyhouse as per standard practice (Maheshwari, 2013). First crop was spawned in October 2016 whereas second crop was spawned in January 2017. Wheat straw was used to prepare compost. Compost was spawned at the rate of $750 \mathrm{~g}$ spawn/quintal of compost and placed in poly bags of $5 \mathrm{~kg}$ capacity as well as in plastic crates of 5-6 kg capacity. Results indicated that spawning of button mushroom was possible in October month that allowed starting the mushroom farming onetwo months earlier. Similarly, polyhouse provided favorable environment in March also thereby further extending the cultivation season by a month.

\section{Conclusions}

The crop cultivation season in hot region of northwestern India is from December - February during which only one crop is grown. The aim of study was to develop crop specific polyhouse that can extend cultivation season and allow growing 2-3 crops. After its construction, thermal analysis of polyhouse was carried out. Polyhouse was provided with two evaporative cooling arrangements. Effect of cooling arrangements on inside temperature and $\mathrm{RH}$ was determined. Results indicated that during October, average ambient air temperature was $31^{\circ} \mathrm{C}$ whereas polyhouse temperature varied from $23-31^{\circ} \mathrm{C}$ when no cooling provided. On operating evaporative cooling system, inside temperature and $\mathrm{RH}$ were changed to $22-27^{\circ} \mathrm{C}$ and $\geq 75 \%$, respectively. These conditions were suitable for spawn run of button mushroom. Similarly, during November, structure could provide $20-22^{\circ} \mathrm{C}$ temperature and $\geq 75 \% \mathrm{RH}$. These conditions were found suitable for case run and to some extent fruiting stage of button mushroom. Similar results were observed in February and March also. Thus study revealed that in hot region, cultivation of button mushroom may be started in October month (one month earlier) and can be carried out till March using developed polyhouse.

\section{Acknowledgement}

Authors duly acknowledge the financial support and facilities provided by All India Coordinated Research Project (AICRP) on Plasticulture Engineering and Technology (PET), ICAR-CIPHET, Ludhiana, India during the course of study.

\section{Conflict of interest}

The authors declare that the research was conducted in the absence of anycommercial or financial relationships that could be construed as a potential conflict of interest.

\section{Author contributions}

All authors have made contributions to the work and writing of this manuscript.

\section{References}

AMGA (2004) The Australian Mushroom Growers Association (AMGA), Locked Bag 3, 2 Forbes St., Windsor, NSW, 2756, Australia.

Anonymous (2017) Horticultural statistics at a glance 2017. Published by Horticulture Statistics Division, Department of Agriculture, Cooperation \& Farmers Welfare, Ministry of Agriculture \& Farmers Welfare, Government of India, Pp:16.

Arumuganathan T, Rai RD, Tewari RP, Kumar R, Khare V, Kamal S (2010) Cultivation of white button mushroom (Agaricus bisporus) under evaporatively-cooled mud house condition. Bangladesh Journal of Mushroom4: 13-18.

Chang R (1996) Functional properties of edible mushrooms. Nutrition Reviews 54: S91-S93.

Dhar BL, Arumuganathan T (2005) Farm design for white button mushroom cultivation. Technical bulletin, National Research Centre for Mushroom, Solan.,Pp. 17. 
Han JH, Kwon HJ, Yoon JY, Kim K, Namb SW, Son JE (2009) Analysis of the thermal environment in a mushroom house using sensible heat balance and 3-D computational fluid dynamics. Biosystem Engineering 104: 417-424.

Holman JP (1989) Heat Transfer. McGraw-Hill Book Co., New York

Karthick K, Hamsalakshmi D (2017) Current scenario of mushroom industry in India. International Journal of Commerce \&Management Research3: 23-26.

Kaur AP, Rampal VK (2017) Assessment of casing mixtures on yield potential and quality of button mushroom (Agaricus bisporus) - on farm trial. International Journal of Current Microbiology and Applied Sciences 6: 430-436.

Kumar B, Kumari C, Kumar M (2018) Comparative Study of the Nutritional Content of White Button Mushroom [Agaricus bisporus (Lange) Imbach] after Application of Pseudomonas putida. International Journal of Current Microbiology \& Applied Sciences7: 2210-2215.

Kwon H, Kang SW, Cho SB (2004) Mushroom growing houses. In: Oyster mushroom cultivation, Mushroom Grower's Handbook 1, Mush World., Chapter 6, Pp. 129-134.

Mabveni ARS (2004) Mushroom cultivation in Zimbabwe. In: Oyster mushroom cultivation, Mushroom Grower's Handbook 1, Mush World., Chapter 10, Pp. 212-219.

Maheshwari SA (2013) Guide for white button mushroom (Agaricus bisporus) production. Open Access Scientific Reports 2 : 1-4. doi.org/10.4172/scientificreports668.

Mehta BK, Jain SK, Sharma GP, Doshi A, Jain HK (2011) Cultivation of button mushroom and its processing: a technoeconomic feasibility. International Journal of Advanced Biotechnology \& Research 2: 201-207.

Reyes RG, Abella EA, Eguchi F, Iijima T, Higaki M, Quimio TH (2004) Growing paddy straw mushrooms. In: Oyster mushroom cultivation, Mushroom Grower's Handbook 1, Mush World. Chapter 11, Pp. 248-255.

Sarker NC, Hossain MM, Sultana N, Mian IH, Karim AJMS, Amin SMR (2008) Relationship between nutrient content in substrates and economic yield of oyster mushroom (Pleurotusostreatus). Bangladesh Journal ofMushroom2: 27-33.

Schiau HG (2013) An investigation of the airflow in mushroom growing structures for modelling new structures. $5^{\text {th }}$ International Conference on Computational Mechanics and Virtual Engineering, 24- 25 October 2013, Brasov, Romania, Pp. 423-429.

Schmidt EL (1983) Spore germination of and carbohydrate colonization by Morchella esculenta at different soil temperatures. Mycologia75: 870-875.

Shekhar S, Suman S, Moharana HS, Sethy DA (2016) Comparative study of performance of six different pad materials in advanced desert coolers. Recent Advances in Mechanical Engineering \& Engineering Materials 250-254.

Stamets P (1993) Cultivating morels mushroom. The Journal of Wild Mushrooming 11: 9-15.

Staunton L (1988) The role of plastics inthe development of the Irish mushroom industry. Plasticulture 79: 22-26.

Thakur MP (2014) Present status and future prospects of tropical mushroom cultivation in India: A review. Indian Phytopathology 67: $113-125$

Van Peer AF, Muller WH, Boekhout T, Lugones LG, Wosten HA (2009) Cytoplasmic continuity revisited: closure of septa of the filamentous fungus Schizophyllum commune in response to environmental conditions. PLoSONE 4 : e5977. https://doi.org/10.1371/journal.pone.0005977.

http://agridaksh.iasri.res.in/html_file/mushroom/white_button_mu sh.htm access on 25th July, 2018. 